\title{
Pengaruh stres kerja terhadap kepuasan hidup pada buruh garmen perempuan di Cicurug Kabupaten Sukabumi
}

\author{
Multazam Al Akbar ${ }^{1}$, Vinaya ${ }^{2 *}$ \\ Fakultas Pendidikan Psikologi, Universitas Pancasila, Indonesia
}

\begin{tabular}{l}
\hline Info Artikel \\
\hline Sejarah Artikel: \\
Diterima \\
3I Desember 2019 \\
Direview \\
04 Agustus 2020 \\
Disetujui \\
30 September 2020 \\
Dipublikasikan \\
30 September 2020 \\
\hline Keywords: \\
Garment labours, \\
Job stress, \\
Life satisfaction, \\
Women.
\end{tabular}

\begin{abstract}
Abstrak
Objektif: Banyaknya industri pengolahan garmen yang ada di Cicurug, Kabupaten Sukabumi membuat sebagian besar perempuan di sana bekerja di pabrik garmen. Salah satu masalah pekerjaan yang dialami oleh buruh di Cicurug adalah target kerja dan jam kerja yang berlebihan. Masalah tersebut sering menjadi pemicu stress sehingga terkadang berdampak pada kepuasan hidup terutama pada buruh garmen perempuan yang sudah menikah. Penelitian ini bertujuan untuk mengetahui apakah ada pengaruh stres kerja terhadap kepuasan hidup pada buruh garmen perempuan di Cicurug, Kab. Sukabumi.
\end{abstract}

Metode: Penelitian ini menggunakan pendekatan kuantitatif dengan desain non eksperimental dengan menggunakan kuesioner. Alat ukur yang digunakan untuk mengukur stres kerja dari Parker dan DeCotiis (1983) dan untuk mengukur kepuasan hidup dari Diener dan Pavrot (dalam Diener, 2008). Sampel penelitian ini adalah 152 buruh garmen perempuan yang sudah menikah. Teknik sampel yang digunakan pada penelitian ini adalah accidental sampling. Metode analisis data dengan menggunakan analisis regresi linear sederhana.

Temuan: Hasil pengolahan data menujukkan bahwa stres kerja tidak berpengaruh terhadap kepuasan hidup buruh garmen di Cicurug, Kab. Sukabumi. Penelitian ini menemukan bahwa sebagian besar responden buruh garmen wanita memiliki tingkat stress kerja yang rendah dan tingkat kepuasan hidup yang juga rendah.

Kesimpulan: Hipotesis penelitian tidak diterima.

\section{Effect of job stress on life satisfaction in female garment labours in Cicurug Kabupaten Sukabumi}

Objectives: The purpose of this study is to determine whether there is influence between job stress to life satisfaction in women garment labours in Cicurug, Sukabumi.

Method: This study used quantitative with non experimental approach, by using questionnaire. The instrument used are job stress questionnaire from Parker and DeCotiis (1983), and life satisfaction scale from Diener \& Pavrot (in Diener, 2008). Sample of this research were 152 married women garment labours. Sampling technique which used in this research is accidental sampling. Data analysis using simple linear regression analysis.

Findings: The result shows that job stress has not influence on the life satisfaction of women garment labours in Cicurug, Sukabumi. Most of the participants in this research have low level in job stress and also low level in life satisfaction.

Conclusions: Research hypothesis is not accepted,

\footnotetext{
*Alamat korespondensi:

Universitas Pancasila Jakarta

Vi3I5naya@gmail.com
} 


\section{Pendahuluan}

Sukabumi merupakan kawasan yang menyimpan potensi pengembangan industri yang cukup baik. Terlebih lagi saat ini Sukabumi dapat dikatakan satu satunya daerah yang berada didekat Jakarta, namun Upah Minimum Regional yang tergolong masih kecil dibandingkan dengan beberapa kota di Jawa Barat seperti Bekasi, Karawang, dan Tanggerang (Ridwan, 2017). Walaupun Sukabumi sudah menjadi kawasan industri, akan tetapi daerah ini masih memiliki masalah kemiskinan. Kemiskinan di Sukabumi masih di bawah rata-rata angka kemiskinan Provinsi Jawa Barat dan Nasional (Radar Sukabumi, 2018).

Salah satu Kecamatan di Sukabumi yang menjadi sentra industri ialah Kecamatan Cicurug. Secara geografis, kecamatan ini memang paling dekat dengan Jakarta, maka tak heran para pengusaha mendirikan pabrik di daerah ini. Banyaknya industri pengolahan garmen yang ada di Cicurug membuat sebagian besar orang bekerja pada pabrik garmen tersebut. Industri garmen adalah industri yang bergerak dibidang pembuatan tekstil yang sudah jadi, seperti pakaian, kaos kaki, dan lainnya (Jala Kapas, 2017).

Garmen merupakan salah satu sektor industri yang mudah menyerap tenaga kerja terutama dari kalangan perempuan (Deny, 2015). Menurut Pemkab Sukabumi sebanyak 70 persen buruh pabrik di Sukabumi ialah perempuan, contohnya seperti pada PT. Pratama Abadi Industri jumlah pekerja laki-laki sebanyak 5.790 orang $(30,01 \%)$ dan perempuan sebanyak 13.500 orang $(69,99 \%)$. Hal tersebut dikarenakan perusahaan menilai buruh perempuan lebih teliti dibandingkan buruh pria terutama dalam urusan menjahit (Nursalikah, 2016).

Sebagian besar buruh perempuan di Cicurug, bekerja dikarenakan suaminya tidak bekerja ataupun memiliki pekerjaan serabutan sehingga ia memilih bekerja menjadi buruh garmen karena disisi lain garmen lebih mudah menerima buruh perempuan dibandingkan pria. Motivasi sebagian besar perempuan untuk bekerja menjadi buruh adalah untuk membantu menghidupi keluarga. Bagi mereka bekerja sangat berarti karena memungkinkan mereka untuk bisa memenuhi kebutuhan hidup bagi keluarganya (Handayani, 2016).

Karolus (2017) menyatakan ada beberapa tantangan kerja yang dialami oleh para buruh perempuan. Tantangan utama terkait dengan sistem kerja kontrak. Sistem kerja kontrak yang dilakukan perusahaan pabrik garmen membuat tidak adanya kejelasan dan jenjang karir bagi para buruh. Tantangan lain adalah jam kerja buruh yang panjang yaitu selama 10 jam per hari dan dituntut untuk kerja lembur dari hari Senin sampai Sabtu, gaji yang kecil dan terbatasnya fasilitas seperti jumlah toilet yang sangat sedikit. Para buruh perempuan umumnya tidak mendapatkan tunjangan selain gaji pokok seperti tunjangan cuti haid dan cuti hamil. Mereka pun kerap mengalami kekerasan fisik, seperti pemukulan, pelemparan benda, gebrakan meja hingga kekerasan yang menyebabkan luka. Salah satu contohnya seperti kasus buruh perempuan di Sukabumi yang mengalami luka bakar di bagian pantat akibat disetrika uap oleh atasannya (Sakti, 20I8).

Ditambah lagi, target kerja yang harus diemban oleh para buruh. Target tersebut seperti dalam 20 menit buruh harus dapat memasang 20 lengan pakaian, 25 menit untuk memasang 40 daun kerah, dan harus membordir 300 logo per satu jam, serta mampu membuat sejumlah pakaian utuh dalam waktu satu jam sesuai dengan target yang ditetapkan. Buruh akan dikenakan sanksi berupa lembur atau skor jam kerja tanpa dibayar jika tidak memenuhi target (Aini, 2017).

Berdasarkan Undang-Undang Ketenagakerjaan Nomor I 3 Tahun 2003, sistem kerja kontrak hanya berlaku paling lama dua tahun dan hanya boleh diperpanjang selama setahun berikutnya. Akan tetapi ditemukan banyak sekali buruh yang bekerja lebih dari 3 tahun namun tetap menjadi pekerja dengan status kontrak (Primastika, 2018). Hal ini membuat para buruh hanya akan menerima upah yang hanya setara UMP tanpa ada tambahan lain kecuali mendapatkan bonus lembur, jika melebihi target kerja.

Terjadi juga kekerasan psikologis pada buruh perempuan. Berdasarkan penelitian yang dilakukan oleh Organisasi Perempuan Mahardhika (dalam Adam, 2018) sebagian besar buruh perempuan yang sudah menikah mengalami kecemasan dan ketakutan ketika ia hamil. Hak cuti hamil yang seharusnya mereka terima sering kali menjadi surat pemutusan kontrak atau permintaan pengunduran diri. Kenyataan yang ada juga menyatakan bahwa sebagian besar buruh yang hamil menyembunyikan kehamilannya. Banyak buruh yang hamil sengaja tidak memberitahukan kehamilannya pada perusahaan sampai kehamilannya terlihat secara visual atau hamil besar. Adapula kasus keguguran yang dialami oleh buruh, dimana hak-hak cuti hamilnya tidak diberikan oleh perusahaan. Kondisi kantor yang tidak bersih serta beban kerja sebagai istri dan pekerja dapat memperparah kondisi kehamilan (Maimunah, 2008). 
Selain itu pelecehan seksual sering dialami oleh buruh perempuan ketika mereka bekerja, ancaman pemutusan kontrak atau beban kerja yang akan ditambah, menjadikan para buruh perempuan tersebut takut untuk menolak pekerjaan yang dibebankan (Pratiwi, 2016). Buruh garmen perempuan yang mengalami pelecehan seksual dapat mengalami rasa takut dan ancaman di tempat kerjanya. Situasi yang tidak aman dan ketidakberdayaan perempuan merubah kesadaran para buruh garmen perempuan, bahwa pelecehan adalah hal yang biasa, sulit dihindari, tidak perlu untuk disuarakan atau dinyatakan (Wusana, Widyawati, \& Pratiwi, 2018).

Hanya saja pada sebagian masyarakat terutama golongan bawah menengah, tidak semua tekanan dapat menjadikan ia tidak puas terhadap kehidupannya. Peneliti melakukan wawancara personal dengan salah satu Supervisor disalah satu pabrik dikawasan Cicurug kab. Sukabumi. Dari hasil wawancara didapati bahwa himpitan ekonomi menjadikan mereka menerima serta membiarkan resiko kerja yang dialaminya. Minimnya pengalaman dan keterampilan membuat mereka sangat bersyukur ketika diterima kerja tanpa mempelajari kontrak kerja. Hal tersebut diungkapkan supervisor (Komunikasi personal, 8 Desember 2018) sebagai berikut:
"Ya gimana ya kebanyakan dari mereka itu buruh dengan ekonomi bawah jadinya kerja di pabrik teh sebuah kebutuhan apalagi suaminya banyak nganggur. Udah gitu disini kan kebanyakan pabrik jadinya yaudah mereka berusaha bisa masuk. Ada juga yang harus keluarin modal dulu buat kursus ngejahit, cuman mengenai isi kontrak ma saya kurang tahu juga, karena saya juga dulu gitu jadi pas tahu keterima teh sudah pasti seneng. Mereka juga ngerasain emang capenya kerja di pabrik, saya juga yang jadi SV ngerasa cape harus gebrakin mereka terus biar kerjanya cepat dan dapat target. Apalagi mereka, jadinya mereka teh santai santai aja dipress terus terusan. Mereka secara sadar memang ngerasain beban kerja yang begitu berat, sedikitnya waktu istirahat yang didapatkan terutama untuk perempuan. Namun itu semua hanya angin lalu bagi mereka, karena didalam benak mereka ialah 'yang penting bisa makan.”'

Durasi bekerja dalam satu hari, pendapatan yang diperoleh perbulan, dan jenis pekerjaan yang dimiliki dapat memengaruhi persepsi seseorang. Seseorang yang bekerja dengan waktu yang lama cenderung akan mengalami kelelahan. Kemudian jika pendapatan yang diperoleh dalam satu bulan serta jenis pekerjaan yang dilakukan tidak sesuai harapannya maka akan berpengaruh pada keadaan dalam hidupnya yaitu kepuasan hidup (Qudsyi, Novitasari, Fakhrunnisak, Ambarito, \& Yudhani, 20I5). Kepuasan hidup merupakan penilaian secara kognitif tentang sejauh mana hal-hal yang dilakukan individu dapat memuaskan secara menyeluruh atas area-area utama dalam hidup yang dianggap penting (domain satisfaction) seperti kesehatan, pekerjaan, hubungan interpersonal, pendapatan, spritualitas dan aktivitas di waktu luang (Diener, 2008)

Diener, Emmons, Larsen, dan Griffin (1985) menyatakan bahwa kepuasan hidup berhubungan dengan karakteristik kepribadian tertentu dan kesejahteraan diri. Beberapa faktor yang dapat memengaruhi kepuasan hidup seseorang adalah kesehatan, realisme dari konsep peran yang berarti semakin berhasil seseorang melaksanakan tugas-tugas perkembangannya maka semakin besar kepuasan hidupnya, status kerja, penghasilan dan pendapatan (Diener, 2008). Diener dan Seligman (dalam Weiten \& Lloyd, 2006) menyatakan bahwa penghasilan mempunyai hubungan yang lemah dengan kebahagiaan. Hal tersebut berarti kemiskinan dapat menyebabkan individu tidak bahagia, namun kekayaan tidak selamanya menyebabkan individu bahagia.

Berdasarkan status pekerjaan, individu merasa puas terhadap hidupnya ketika dia menikmati pekerjaannya dan merasa pekerjaan tersebut adalah penting. Sebaliknya jika individu merasa pekerjaannya buruk dikarenakan lingkungan pekerjaan yang buruk dan tidak sesuai dengan diri, individu tidak akan merasa puas dalam kehidupannya (Diener, 2008). Situasi seperti yang dialami buruh, secara negatif dapat mempengaruhi emosi, proses berpikir, dan kondisi mereka. Hal tersebut terjadi karena adanya ketegangan dalam diri, yang menjadikan orang tersebut cemas dan merasakan kekhawatiran kronis. Kondisi seperti ini disebut dengan stres. Orang yang sedang stres cenderung sering marah-marah, agresif, tidak dapat rileks, atau memperlihatkan sikap yang tidak kooperatif (Hasibuan, 2003)

Stres kerja merupakan sebuah penyimpangan perasaan seseorang dari keadaan normal atau keadaan yang diinginkan oleh diri sendiri di tempat kerja sebagai hasil dari peluang, kendala, atau tuntutan yang berkaitan dengan hasil dari pekerjaan (Parker \& DeCotiis, 1983). Menurut Parker dkk., ada dua aspek yang paling mempengaruhi stres kerja yaitu tekanan waktu dan kekhawatiran. Tekanan waktu terkait erat dengan perasaan berada di bawah tekanan waktu ketika bekerja. Sedangkan kekhawatiran didominasi oleh hal-hal yang berkaitan dengan perasaan cemas terhadap pekerjaan.

Berdasarkan riset dari Health and Safety Executive di Inggris tahun 2016, diketahui bahwa perempuan lebih rentan stres dibandingkan pria. Usia perempuan yang rentan stress adalah 25 sampai 54 tahun, namun 
tingkat stres yang tinggi dialami pada perempuan dengan usia 35 hingga 44 tahun. Penyebab perempuan stres adalah kesulitan menyeimbangkan tugas sebagai karyawan dan ibu rumah tangga. Pada seorang perempuan yang sudah berkeluarga cenderung memiliki stres kerja yang tinggi dikarenakan konflik peran yang dialaminya. Konflik peran tersebut bersamaan dengan peran organisasi dan peran dalam rumah tangganya. Sehingga perempuan yang bekerja memiliki tingkat stress yang lebih tinggi dibandingkan pria yang bekerja (Anjani, 2017).

Beragam akibat dari stres kerja, antara lain kejenuhan kerja. Hal ini merupakan hal yang paling umum terjadi. Gejala dari kejenuhan kerja ini adalah kebosanan, depresi, pesimisme, kurang konsentrasi, kualitas kerja buruk, dan ketidakpuasan. Ketidakpuasan yang dihasilkan dari stres kerja berdampak pada kehidupan seharihari dimana karena ketidakpuasan hidup orang-orang dapat menjadi depresi. Sayangnya, stres kerja masih sulit untuk dibicarakan dengan para atasan. Banyak dari para pekerja mengaku bahwa mereka takut kehilangan pekerjaannya atau tidak dipromosikan jika mereka terus menerus menjadikan stres kerja sebagai penyebab menurunnya kinerja mereka (National Safety Council, 2003).

Penelitian sebelumnya menyatakan bahwa stres dan kepuasan mempunyai hubungan yang berbanding terbalik atau bersifat negatif. Semakin tinggi tingkat stress maka semakin rendah kepuasannya. Hal tersebut berarti ketika seseorang puas maka secara langsung dapat meningkatkan daya tahan individu dalam menghadapi stres. Kemudian stres yang dihadapi oleh pekerja dapat menjadi sumber ketidakpuasan (Felanny, 20I3).

Selanjutnya pada penelitian Naseem (2018) yang dilakukan pada karyawan sektor telekomunikasi di Pakistan menyatakan bahwa stres merupakan prediktor yang signifikan terhadap kebahagiaan dan kepuasan hidup. Dalam penelitian ini ditemukan bahwa pria yang sudah menikah lebih effisien mengendalikan stress dibandingkan perempuan. Pada penelitian lain yang dilakukan oleh Mutiu (2016) menunjukan bahwa ada hubungan yang signifikan antara stres kerja dan kepuasan hidup. Selain itu dalam penelitian inipun ditemukan bahwa semakin lama pengalaman kerja maka semakin puas seseorang terhadap kehidupannya. Sampel pada penelitian ini sebanyak 120 staff administrasi non akademik di Universitas Islam Internasional Malaysia.

Berdasarkan teori-teori, dan penelitian-penelitian sebelumnya, peneliti tertarik meneliti apakah stres kerja juga memiliki pengaruh terhadap kepuasan hidup pada buruh garmen perempuan mengingat hasil penelitian sebelumnya menujukkan adanya hubungan yang signifikan antara stres kerja dengan kepuasan hidup. Variabel stres kerja dan kepuasan hidup tersebut masih layak untuk diteliti dengan adanya beberapa perbedaan dari penelitian sebelumnya. Pada penelitian sebelumnya metode yang dipakai adalah metode korelasi, sedangkan penelitian ini berfokus pada adanya pengaruh stres kerja dengan kepuasan hidup. Kemudian fenomena yang terjadi pada penelitian ini adalah banyaknya masalah pekerjaan yang dialami oleh buruh di Cicurug, beberapa masalah seperti target kerja, jam kerja yang berlebihan, dan beberapa masalah yang terjadi pada buruh perempuan yang sudah menikah. Masalah tersebut sering menjadi pemicu stress sehingga terkadang berdampak pada kepuasan hidup. Berdasarkan hasil wawancara awal, peneliti menemukan bahwa bagi beberapa buruh perempuan, stress dianggap merupakan hal wajar karena tuntutan mencari nafkah dan bekerja adalah pilihan satu-satunya untuk menghidupi diri dan keluarganya. Penelitian ini juga dilakukan di Cicurug karena Cicurug merupakan kawasan industri yang sedang berkembang dan paling dekat dengan Jakarta. Industri yang paling banyak di Cicurug adalah industri garmen dan paling banyak juga menyerap tenaga kerja perempuan. Sehingga peneliti tertarik untuk meneliti pengaruh stres kerja terhadap kepuasan hidup pada buruh garmen perempuan di Cicurug Kab. Sukabumi. Tujuan penelitian ini adalah untuk mengetahui apakah terdapat pengaruh Stres Kerja terhadap Kepuasan Hidup pada buruh garmen perempuan yang pernah menikah di Cicurug Kab.Sukabumi. Hasil penelitian ini diharapkan bermanfaat sebagai tambahan literatur mengenai pengaruh stres kerja terhadap kepuasan hidup pada buruh garmen perempuan yang pernah menikah di Cicurug Kab.Sukabumi. dan diharapkan bisa juga menjadi bahan kajian bagi pemilik perusahaan atau pemerintah untuk bisa membuat kebijakan atau peraturan kerja yang lebih menyejahterakan untuk para pekerja perempuan yang sudah menikah.

\section{Metode}

Penelitian ini menggunakan pendekatan kuantitatif dengan desain non eksperimental karena peneliti tidak melakukan kontrol terhadap variable bebas dan variable terikat yang terkait dengan topik penelitian (Kumar, 20II), karena penelitian ini bertujuan untuk melakukan pengujian hipotesis melalui perhitungan statistik, sehingga hasil penelitian dapat digeneralisasikan dan tidak menggunakan control yang ketat. Secara spesifik, 
pendekatan yang dilakukan bersifat kausal karena ingin melihat pengaruh stress kerja terhadap kepuasan hidup.

Populasi dalam penelitian ini adalah buruh perempuan yang bekerja sebagai buruh pabrik garmen di Cicurug Kab.Sukabumi. Sampel atau responden yang akan dijadikan subjek dalam penelitian ini adalah buruh garmen perempuan yang pernah menikah di Cicurug, Kab.Sukabumi.

Teknik non probability sampling yang digunakan adalah accidental sampling. Accidental sampling adalah teknik penentuan sampel yang dilakukan secara spontanitas, artinya individu yang dengan ketidaksengajaan bertemu dengan peneliti dan sesuai karakteristik maka individu tersebut dapat dijadikan sebagai responden (Creswell, 20I2).

Jumlah awal responden penelitian adalah sebanyak 186 responden, namun 34 responden gugur dikarenakan tidak sesuai dengan kriteria penelitian, sebanyak 152 responden buruh perempuan yang sudah menikah di Cicurug Kabupaten Sukabumi diolah lebih lanjut.

Alat ukur yang digunakan di dalam penelitian ini menggunakan skala stres kerja dari Parker dan DeCotiis (1983) dengan 2 dimensi yaitu time pressure dan anxiety. Skala ini terdiri dari 13 item. Dari 13 item, berdasarkan uji coba alat ukur diperoleh 8 item yang valid, dengan nilai cronbach's Alpha sebesar 0,78. Contoh item dimensi time pressure adalah "Saya menghabiskan banyak waktu untuk pekerjaan saya.", sedangkan contoh item anxiety adalah "Saya merasa cemas dengan hasil pekerjaan saya." Jawaban setiap item menggunakan skala Likert dengan 4 kategori respon yaitu sangat setuju (ss), setuju (s), tidak setuju (ts), dan sangat tidak setuju (sts).

Instrumen untuk mengukur kepuasan hidup dari Diener dan Pavrot (dalam Diener, 2008) yang terdiri dari 5 item. Berdasarkan hasil uji coba, terdapat I item yang tidak valid, sehingga hanya terdapat 4 item yang lebih lanjut disebarkan untuk pengambilan data, dengan skor cronbach's Alpha sebesar 0,742. Contoh item kepuasan hidup adalah "Saya puas dengan hidup saya." Jawaban setiap item menggunakan skala Likert dengan 4 kategori respon yaitu sangat setuju (ss), setuju (s), tidak setuju (ts), dan sangat tidak setuju (sts).

Uji normalitas dilakukan dengan one-sample kolmogorov-smirnov memperoleh skor sebesar 0,3I4 dengan demikian dapat diketahui bahwa data diperoleh terdistribusi dengan normal, hal ini dikarenakan skor yang didapatkan di atas skor minimal yaitu 0,05 .

\section{Tabel I}

\section{Deskripsi Subjek Penelitian}

\begin{tabular}{ccc}
\hline Kriteria & Frekuensi & Presentase \\
\hline Usia & & \\
$20-30$ & 108 & $71,1 \%$ \\
$31-40$ & 39 & $25,6 \%$ \\
$41-50$ & 5 & $3,3 \%$ \\
Lama bekerja & & \\
I-5 & 106 & $69,7 \%$ \\
$6-10$ & 41 & $27 \%$ \\
II-19 & 5 & $3,3 \%$ \\
Jumlah anak & & \\
0 & 63 & $41,4 \%$ \\
I & 48 & $31,6 \%$ \\
2 & 26 & $17,1 \%$ \\
3 & 11 & $7,2 \%$ \\
4 & 2 & $1,3 \%$ \\
5 & 2 & $1,3 \%$ \\
\hline
\end{tabular}

\section{Hasil}

Hasil utama penelitian ini menunjukkan bahwa tidak terdapat pengaruh stress kerja terhadap kepuasan hidup pada buruh garmen perempuan di Cicurug Kab. Sukabumi, $F(I, I 50)=1,578, p=2, I I, R^{2}=0,000$. 
Analisis berdasarkan tinggi rendahnya stres kerja dan kepuasan hidup didapat bahwa sebagian besar responden berada pada tingkat stres kerja yang rendah, yaitu sebesar $51,3 \%$ dengan frekuensi 78 responden. Pada kategorisasi kepuasan hidup dominan berada pada tingkat rendah, yaitu sebesar $58,6 \%$ dengan frekuensi 89 responden.

\section{Pembahasan}

Berdasarkan hasil dari penelitian, diketahui bahwa stres kerja tidak mempengaruhi kepuasan hidup. Hal ini tidak sejalan dengan Diener (2008) yang menyatakan individu merasa puas terhadap hidupnya ketika dia menikmati pekerjaannya dan merasa pekerjaan tersebut adalah penting. Sebaliknya jika individu merasa pekerjaannya buruk dikarenakan lingkungan pekerjaan yang buruk dan tidak sesuai dengan diri, dalam hal ini dapat berupa stres, maka individu tidak akan merasa puas dalam kehidupannya. Namun, pada penelitian ini ditemukan bahwa sebagian besar responden memiliki level stres kerja yang rendah, begitu juga nilai kepuasan hidup pada buruh wanita ditemukan sebagian besar berada pada level rendah. Hal ini berarti bahwa tekanan pada pekerjaan tidak membuat stres, dan juga tidak membuatnya puas terhadap hidup para partisipan buruh perempuan di dalam penelitian ini.

Penelitian ini berbeda dari penelitian-penelitian sebelumnya, seperti pada penelitian Mutiu (2016) yang menunjukan bahwa ada hubungan yang signifikan antara stres kerja dan kepuasan hidup pada 120 staff administrasi non akademik di Universitas Islam Internasional Malaysia dan juga penelitian Naseem (2018) pada karyawan sektor telekomunikasi di Pakistan yang menemukan bahwa stres kerja merupakan prediktor yang signifikan terhadap kebahagiaan dan kepuasan hidup.

Perbedaan hasil penelitian ini dengan penelitian sebelumnya tersebut, kemungkinan terkait dengan tipe pekerjaan. Ada dua tipe pekerja yaitu blue-collar workers dan white coral workers. Blue-coral workers adalah pekerja yang melakukan pekerjaan fisik dan karirnya relatif terbatas. Sedangkan white-collar workers sebagai seorang pekerja professional dan semi-profesional (Gibson \& Papa, 2000). Buruh garmen termasuk ke dalam blue-coral workers dimana mereka melakukan pekerjaan yang menggunakan tenaga fisik. Pekerjaan ini tidak memerlukan pendidikan tinggi untuk dapat bekerja, sehingga banyak dari blue-collar workers ini adalah kaum menengah bawah.

Evaluasi dari penelitian ini, peneliti menemukan penerimaan terhadap stres kerja yang diterima oleh buruh dikarenakan kebutuhan akan pekerjaan untuk menafkahi keluarga yang menjadikan mereka cenderung bersyukur dengan apa yang mereka dapatkan. Sebagian besar responden di dalam penelitian ini berasal dari suku Sunda. Dalam budaya Sunda dikenal sebuah istilah 'cikaracak ninggang batu laun laun jadi legok' yang memiliki arti apabila melakukan sesuatu dengan sungguh-sungguh, meskipun sulit pasti akan bisa dilalui. Istilah ini diturunkan secara turun temurun sebagai pesan agar manusia selalu bersyukur dan melakukan dengan sungguh-sungguh segala hal yang kita terima. Kebahagiaan seringkali tergantung pada sikap penerimaan dan menikmat keadaan pada individu (Shaver \& Freedman dalam Hurlock, 1997).

Hasil penelitian juga bisa dijelaskan menurut teori social justice (Jost, 2010). Di dalam teori social justice dikatakan bahwa orang ingin bertahan hidup dan memenuhi kebutuhan keluarganya. Mereka terkadang tidak memiliki pilihan lain selain menghasilkan kekayaan kaum kapitalis yang mengendalikan sektor industri. Selain itu, orang sering memutuskan apakah mereka telah diperlakukan secara adil dengan membandingkan situasi mereka sendiri dengan situasi yang relevan (Jost, 2010). Dalam kasus ini buruh membandingkan situasi mereka dengan kolega mereka di pabrik yang juga memiliki keadaan yang tidak jauh berbeda dengan mereka. Bahkan sebagian dari mereka merasa sangat beruntung dibandingkan orang disekitar mereka yang tidak memiliki pekerjaan. Buruh dibiasakan untuk terus bekerja dengan pekerjaan yang sama oleh perusahaan sehingga mereka tidak merasakan sedang di eksploitasi, desakan untuk memenuhi kebutuhan hidup dan keinginan untuk bisa mengikuti zaman, membuat mereka terbiasa untuk terus bekerja dengan waktu yang panjang (Mundayat,2008).

Tantangan di dalam penelitian ini adalah sulitnya mencari responden penelitian. Peneliti mendapatkan penolakan dari garmen - garmen yang peneliti datangi untuk menyebarkan kuesioner. Meskipun sudah mendapatkan surat ijin penelitian dari pihak Universitas dan berusaha melakukan pendekatan dengan HRD di perusahaan garmen, namun peneliti tidak dapat menyebarkan kuesioner melalui jalur tersebut. Akhirnya peneliti menyebar kuesioner dengan pendekatan personal, datang ke rumah-rumah untuk mendapatkan partisipan buruh wanita sesuai dengan kriteria penelitian. Sebagian dari calon partisipan yang sesuai kriteria ditemukan enggan mengisi kuesioner, karena memiliki perasaan takut, seperti takut dilaporkan ke tempat ia 
bekerja, dan takut mengisi pernyataan dengan jawaban yang salah. Hal itu bisa dilihat dari dianulirnya 34 kuesioner penelitian. Kemudian dikarenakan penelitian ini berdekatan dengan tahun politik di Indonesia, hal ini membuat para responden maupun non responden (petugas keamanan garmen) merasa curiga bahwa peneliti sedang melakukan penelitian untuk partai politik tertentu.

Secara umum penelitian ini menunjukkan bahwa seberapa pun beratnya tekanan pekerjaan, pemaknaan terhadap pekerjaanlah yang menentukan apakah tekanan tersebut menyebabkan stress. Pada blue-coral workers seperti buruh, yang melakukan pekerjaan fisik dan karirnya relatif terbatas, terlihat bahwa memiliki pekerjaan saja sudah sebuah hal yang patut disyukuri karena mereka masih bisa memenuhi kebutuhan keluarga. Hal ini menunjukkan bahwa hasil penelitian yang selama ini diterima memiliki keterhubungan terutama pada sample white coral workers yang memang lebih banyak diteliti dalam kajian psikologi, boleh jadi menunjukkan hasil yang berbeda pada sampel blue coral workers.

\section{Kesimpulan}

Berdasarkan hasil analisis yang telah dilakukan, maka dapat disimpulkan bahwa stres kerja tidak berpengaruh terhadap kepuasan hidup pada buruh garmen perempuan di Cicurug Kab. Sukabumi. Berdasarkan hal tersebut, saran untuk penelitian selanjutnya adalah penelitian terhadap buruh lebih mudah jika peneliti sudah memiliki link dan mampu melakukan pendekatan personal dengan staff HRD di perusahaan garmen. Surat keterangan penelitian dari fakultas hendaknya selalu dibawa supaya mengurangi kecurigaan ketika mengambil data.

Tidak adanya pengaruh antara stress kerja dan kepuasan hidup di dalam penelitian ini membuat penelitian lebih lanjut secara mendalam melalui metode kualitatif diperlukan untuk menggali alasan kecenderungan rendahnya stress kerja pada buruh.

\section{REFERENSI}

Adam, A. (2018, Desember 3). Tangan dan Kaki Terikat: Buruh Perempuan di Cakung Dilarang Hamil. Dipetik Desember 3, 2018, dari tirto.id: https://tirto.id/tangan-dan-kaki-terikat-buruh-perempuan-di-cakungdilarang-hamil-daRr

Aini, N. (2017, Desember 19). Pekerja Pabrik Garmen Ketakutan Saat Hamil, Ini Alasannya. Dipetik 12 03, 2018, dari Republika.co.id: https://www.republika.co.id/berita/nasional/hukum//7//2//9/p I74ky382pekerja-pabrik-garmen-ketakutan-saat-hamil-ini-alasannya

Anjani, R. (2017, Januari 4). Pekerja Wanita Lebih Mudah Stres Dibanding Pria, Ini Penyebabnya. Dipetik November 24, 2018, dari Wolipop: https://m.detik.com/wolipop/work-and-money/d3387873/pekerja-wanita-lebih-mudah-stres-dibanding-pria-ini-penyebabnya

Creswell, J. W. (2012). Research Design Pendekatan Kualitatif, Kuantitatif, dan Mixed. Yogyakarta: Pustaka Pelajar.

Deny, S. (2015, Oktober 15). BKPM: Industri Tekstil Jadi Andalan Penyerapan Tenaga Kerja. Dipetik Oktober 22, 2018, dari Liputan6: https://www.liputan6.com/bisnis/read/2340688/bkpm-industri-tekstil-jadiandalan-penyerapan-tenaga-kerja

Diener, R. B. (2008). Material wealth and subjective well-being. Portland State University, 307-322.

Diener, E., Emmons, R. A., Larsen, R. A., \& Griffin, S. (1985). The Satisfaction with Life Scale. Journal od Personality Assessment, 49(I), 7I-75.

Felanny, F., \& Moerkardjono, S.R. (20|3). Hubungan stres kerja dan kepuasan kerja pada karyawan perusahaan X. Jurnal NOETIC Psychology, 3 (2), 196-207.

Gibson, M. K., \& Papa, M. J. (2000). The mud, the blood and the beer guys: Organizational osmosis in bluecollar work-groups. Journal of Applied Communication Research, 28, 68-88. 
Handayani, M. T. (2016). Karakteristik Dinamis Peran Ganda Pekerja Wanita di Sektor Informal. Agrineca, 17, 13-24.

Hasibuan, H. M. (2003). Manajemen Sumber Daya Manusia. Jakarta: Bumi Aksara.

Hurlock, E. B. (I99I). Psikologi Perkembangan : Suatu Pendekatan Sepanjang Rentang Kehidupan. Jakarta: Erlangga.

Jost, J. T. (2010). Social Justice: History, Theory, and Research. Dalam J. T. Jost, Social and Psychological Bases of Ideology and System Justification (hal. I I22-I I65). New York: Stanford.

Karolus, A. (2017). Buruh Kontrak di Sukabumi. Diunduh Oktober 28, 2018, dari http://majalahsedane.org/sistem-kerja-kontrak-mendung-menggelayut-di-sukabumi/

Kumar, R. (20I I). Methodology 3 rd ed. Los Angeles: Sage.

Maimunah, M. A. (2008). Kesadaran tentang Perlindungan Kesehatn Reproduksi: Kasus Buruh Perempuan di Kawasan Berikat Nusantara (KBN) Tanjung Priok. Dalam A. A. Mundayat, E. Agustini, K. Sukesi, \& M. A. M, Bertahan Hidup di Desa atau Tahan Hidup di Kota: Balada Buruh Perempuan (hal. 67-104). Jakarta: Women Research Institute.

Mundayat, A. A. (2008). Moral Ekonomi Perempuan Pabrik: Dinamika Kehidupa di Tempat Kerja. Dalam A. A. Mundayat, E. Agustini, K. Sukesi, \& M. A. M, Bertahan Hidup di Desa atau Tahan Hidup di Kota: Balada Buruh Perempuan (hal. I-33). Jakarta: Women Research Institute.

Mutiu, S. (TT). The Relationship between Stres Kerja and Kepuasan Hidup among Non-Academic University Staffs. Department of Psychology, International Islamic University Malaysia.

Naseem, K. (2018). Job Stress, Happiness and Life Satisfaction: The Moderating Role of Emotional Intelligence Empirical Study in Telecommunication Sector Pakistan. Journal of Social Sciences and Humanity Studies, 4(I), 7-14.

National Safety Council. (2003). Manajemen Stres. (P. Widyastuti, Penerj.) Jakarta: EGC.

Nursalikah, A. (2016, November 02). Buruh Pabrik di Sukabumi 70 Persen Perempuan. Dipetik Oktober 28, 2018, dari Republika.co.id: https://www.republika.co.id/berita/nasional/daerah/I6/I //02/og08dp366buruh-pabrik-di-sukabumi-70-persen-perempuan

Perbedaan tekstil dan garmen. (2017, September 27). Diunduh Oktober 24, 2018 dari http://www.jalakapas.com/?p=434

Parker, D. E., \& DeCotiis, T. A. (1983). Organizational Determinants of Stres Kerja . Organizatioal Behavior and Human Performance, 32, $160-177$.

Pratiwi, P. S. (2016, November 24). Buruh Pabrik Garmen Sering Alami Kekerasan Seksual . Dipetik Desember 4, 2018, dari CNN Indonesia: https://www.cnnindonesia.com/nasional/20161/24152933-20I75048/buruh-pabrik-garmen-sering-alami-kekerasan-seksual

Primastika, W. (2018, Desember 3). Eksploitasi Kerja Kontrak Melanggengkan Pelecehan Seksual. Dipetik Desember 3, 2018, dari tirto.id: https://tirto.id/eksploitasi-kerja-kontrak-melanggengkan-pelecehanseksual-daRV

Qudsyi, H., Novitasari, R., Fakhrunnisak, Ambarito, T. P., \& Yudhani, E. (20I5). Kepuasan Hidup Orang yang Bekerja Ditinjau dari Faktor Pribadi, Pekerjaan, dan Pasangan (Kepuasan Hidup). Makalah Seminar Nasional UII 2015, I-16.

Radar Sukabumi. (2018, Juli 21). BPS Sebut Angka Kemiskinan Menurun. Diunduh Oktober 24, 2018, dari Radar Sukabumi: https://radarsukabumi.com/2018/07/2I/bps-sebut-angka-kemiskinan-menurun/

Ridwan. (2017, Januari 7). Sukabumi Menyimpan Potensi Besar untuk Kawasan Industri. Diunduh Oktober 23, 2018, dari http://m.industry.co.id/read/23/4/sukabumi-menyimpan-potensi-besar-untuk-kawasanindustri 
Sakti, D. (2018, Agustus 24). Parah! Buruh PT Dosan Sukabumi Disetrika Atasan. Dipetik Desember 4, 20I8, dari Pojokjabar.com: https://jabar.pojoksatu.id/sukabumi/2018/08/25/parah-buruh-pt-dosansukabumi-disetrika-atasan/

Weiten, W., \& Lloyd, M. A. (2006). Psychology Applied Modern Life: Adjustment in The 2 Ist Century. California: Thomson Higher Education.

Wusana, S. W., Widyawati, V., \& Pratiwi, M. I. (2018). Pelecehan Seksual dan Pengabaian Hak Maternitas pada Buruh Garmen. Jakarta: Perempuan Mahardhika. 